\title{
Sedimentary Environments and Correlative Sequence Stratigraphy of Upper Cretaceous-Paleogene Succession in Shiraz Area, Fars, SW IRAN
}

\author{
Mirzaee Mahmoodabadi Reza \\ Department of Geology, Estahban Branch, Islamic Azad University, Estahban, Iran \\ Email: r mirzaeem@iauest.ac.ir, rmirzaeem1@Hotmail.com
}

Received December 2, 2013; revised December 28, 2013; accepted January 5, 2014

Copyright (C 2014 Mirzaee Mahmoodabadi Reza. This is an open access article distributed under the Creative Commons Attribution License, which permits unrestricted use, distribution, and reproduction in any medium, provided the original work is properly cited. In accordance of the Creative Commons Attribution License all Copyrights (C) 2014 are reserved for SCIRP and the owner of the intellectual property Mirzaee Mahmoodabadi Reza. All Copyright (C 2014 are guarded by law and by SCIRP as a guardian.

\begin{abstract}
Sequence stratigraphic evidences have been used in this research to investigate the stratigraphic correlation of cretaceous paleogene succession in Shiraz area, Fars, SW Iran. For this purpose, 4 stratigraphic sections have been chosen and provided. According to petrographic study and field evidences, 4 depositional sequences were identified including the Tarbur, Sachun and Jahrum formations in the east and the Gurpi, Pabadeh and Asmari formations in the west of study area. After identifying the boundaries and systems tract facies, it has been found that the mentioned formations have been deposited among the continuous/discontinuous boundaries in an equivalent manner. In this case, the purple shale (between the Gurpi and Pabdeh formations) could be considered equivalent to the upper part of the Sachun formation. From the point of Paleogeography, the plat-form sedimentary environment covered almost the whole area during the Oligo-Miocene age, so that the Asmari formation would have been deposited, which is marked by sharp contact as disconformity on Jahrum formation in the east of the basin and with continuous contact (C.C) on the Pabdeh formation in the west and southwest.
\end{abstract}

\section{KEYWORDS}

Iran; Fars; Shiraz; Sedimentary Environment; Sequence Stratigraphy; Cretaceous-Tertiary Boundary

\section{Introduction}

Upper cretaceous sediments in study area cover two formations: Gurpi and Tarbur. Gurpi formation consists of shale and marl and Tarbur formation formed of reef massive limestone. Paleogene sediments in the Shiraz region cover four formations: Sachun, Jahrum, Pabdeh, and Asmari. The mentioned formations are expanded over the studied area with a petrological variety of marl, limestone, dolomite, dolomitic limestone and evaporate rock with different thicknesses [1]. The sequence stratigraphic evidences have been applied in this research to study the stratigraphic conformity and correlation of the formations in the upper cretaceous-paleogene time frame. Such studies would have application in paleogeography and the evolution of the Zagros sedimentary basin in this period.

\section{Materials and Methods}

The research method includes four general stages: 1) collecting data (from new references) and studying aerial photographs, initial field visits; 2) field survey, taking field photos, preparing thin sections and providing photos from thin sections; 3) data analysis and interpretation of the results; 4) presenting depositional environments models and the stratigraphic correlation of under study formations. For this purpose, after full field survey, 4 stratigraphic sections including 1) Sarvestan section; 2) Estahban section; 3) Mook section; and 4) Shahneshin section, were selected and studied.

\section{Geologic and Stratigraphic Setting}

The study area is located SW of the Zagros Mountains, 
which is a cretaceous-paleogene sediments in foldthrust belt Zagros that located in Fars area. The Zagros is the result of a multi-phased collision between the Arabian plate, the Neo-Tethys ocean, and the central Iran microplate [2]. In study area Tarbur, Sachun, Jahrum, Gurpi, Pabdeh and Asmari formations are expanded all over the in the cretaceous-Tertiary boundary CTB and Paleogene period. The selected sections include one, two or three rock units based on the case. As such, the Estahban and Sarvestan sections includes four formations of Tarbur, Sachun, Jahrum and Asmari, the Mook and Shahneshin sections covers the Gurpi, Pabdeh and Asmari formations. Figure 1 showes the geological setting and Geographical location of the studied sections.

\section{Lithostratigraphy of the Studied Sections}

The geographic coordinates of the base of the selected sections, together with their lithostratigraphical characteristics are summarized in Table 1. Figure 2 shows lithostratigraphical relationship between formations in Fars area, SW of Iran and Figures 3-5 show some field photos of study area.

\section{Microfacies \& Depositional Environments Model Based on the Relative Sea Level Changes}

A wide range of carbonate, clastic (Litofacies) and evaporite facies have been identified in petrographic and field studies of the studied formations. Type of skeletal and non-skeletal grains, grain size and their frequency percentage, Matrix and cement have been used to discriminate and identify carbonate facies from factors such as constituents of carbonate rocks including orthochem and allochem. Skeletal grains are mostly from Miliolidae, Algae, Nummulitidae, Globigerinidae, Globorotruncanidae Discocyclinidae, Lepidocyclynidae and Alveolinidae families. For determination of carbonate microfacies use of Flugel 2004 [3].

Non-skeletal grains include pellet and intraclast, the frequency of which in some samples reaches to $50 \%$. Nomenclature of the carbonate samples has been carried out by Dunham method [4]. In general, having precisely

Table 1. The geographic coordinates and lithostratigraphy of the studied sections.

\begin{tabular}{|c|c|c|c|c|c|c|c|}
\hline No & Section Name & Formation & Lithology & Coordinate U.T.M & Lower Limit & Upper Limit & Thick (m) \\
\hline 1 & Sarvestan & $\begin{array}{l}\text { Tarbur, Sachun, } \\
\text { Jahrum, Razak }\end{array}$ & $\begin{array}{l}\text { Red and Green Marl, Evaporate } \\
\text { (Jepsum \& Anhydrite),Limestone, } \\
\text { Dolomit, Dolomitic Limestone }\end{array}$ & $\begin{array}{c}53^{\circ} 30^{\prime} 45^{\prime \prime} \mathrm{E} \\
29^{\circ} 7^{\prime} 50^{\prime \prime} \mathrm{N}\end{array}$ & $\begin{array}{c}\text { Tarbur, } \\
\text { CTB Boundary }\end{array}$ & Razak & 570 \\
\hline 2 & Estahban & $\begin{array}{l}\text { Tarbur, Sachun, } \\
\text { Jahrum, Asmari }\end{array}$ & $\begin{array}{l}\text { Limestone, Dolomite, } \\
\text { Dolomitic Limestone }\end{array}$ & $\begin{array}{l}53^{\circ} 55^{\prime} 36^{\prime \prime} \mathrm{E} \\
29^{\circ} 7^{\prime} 50^{\prime \prime} \mathrm{N}\end{array}$ & $\begin{array}{c}\text { Tarbur, } \\
\text { CTB Boundary }\end{array}$ & Razak & 226 \\
\hline 3 & Mook & $\begin{array}{l}\text { Gurpi, Pabdeh, } \\
\text { Asmari }\end{array}$ & $\begin{array}{l}\text { Dark, Pale Yellow, gray and slightly } \\
\text { blue Shale and Marl, Calcareous Shale, } \\
\text { Limestone and Calciturbidite Sediments }\end{array}$ & $\begin{array}{l}52^{\circ} 10^{\prime} 30^{\prime \prime} \mathrm{E} \\
29^{\circ} 4^{\prime} 10^{\prime \prime} \mathrm{N}\end{array}$ & $\begin{array}{c}\text { Purple Shale, SB2, } \\
\text { CTB Boundary }\end{array}$ & $\begin{array}{l}\text { Asmari, } \\
\text { Gachsaran }\end{array}$ & 400 \\
\hline 4 & Shahneshin & $\begin{array}{l}\text { Gurpi, Pabdeh, } \\
\text { Asmari }\end{array}$ & $\begin{array}{l}\text { Dark, Pale Yellow, gray and slightly } \\
\text { blue Shale and Marl, Calcareous Shale, } \\
\text { Limestone and Calciturbidite Sediments }\end{array}$ & $\begin{array}{l}55^{\circ} 55^{\prime} 50^{\prime \prime} \mathrm{E} \\
29^{\circ} 24^{\prime} 40^{\prime \prime} \mathrm{N}\end{array}$ & $\begin{array}{c}\text { Purple Shale, SB2, } \\
\text { CTB Boundary }\end{array}$ & $\begin{array}{c}\text { Asmari, } \\
\text { Gachsaran }\end{array}$ & 500 \\
\hline
\end{tabular}

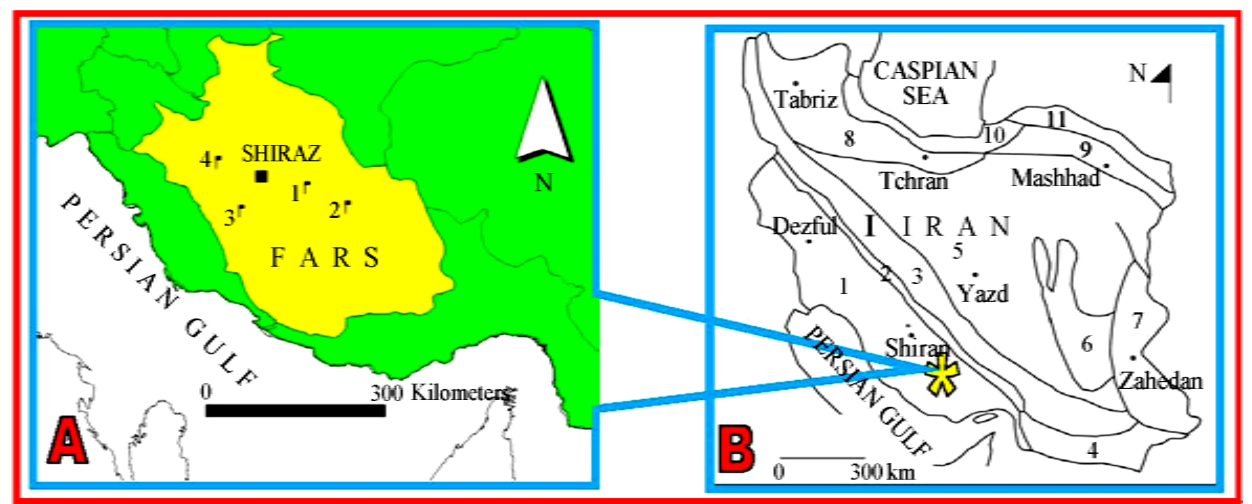

Figure 1. A: Geographical situation of the studied section in study area: 1-Sarvestan section; 2-Estahban section; 3Mook section; 4-Shahneshin section. B: Tectono-sedimentary provinces of Iran and the location of the study area. 1Folded Zagros; 2-High Zagros; 3-Esfandaghe-Marivan, 4-Makran; 5-Central Iran; 6-Lut Block; 7-NehbandanKhash, 8-Alborz-Azarbayejan, 9-Binalud, 10—Gorgan-Rasht, 11—Hezarmasjed-Kopedagh; *study area. 


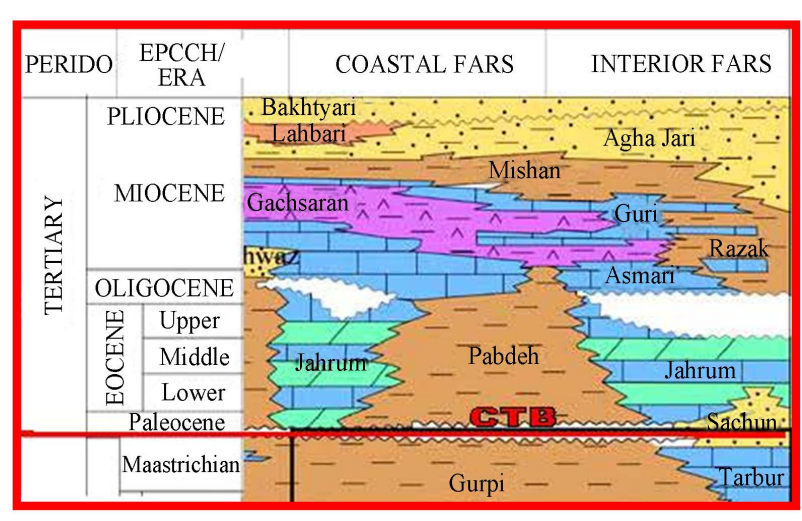

Figure 2. Lithostratigraphical relationship between formations in Fars area, SW of Iran (Modified of James \& Wynd, 1975).

carried out the study and nomenclature of microfacies, the depositional model of each of the formations under study has been brought out according to the relative changes curve of the sea level based on their time.

All in all, about 800 thin sections have been provided from the 4 studied sections and after precise study of the samples, the facies of the Tarbur, Gurpi, Sachun, Jahrum, Pabdeh and Asmari formations were studied in detail, the abstract of which has been brought out in the following tables.

\subsection{Microfacies of Tarbur Formation}

Tarbur formation expanded in Sarvestan and Estahban sections. Tarbur Formation in study area is divided into two lithostratigraphic parts which are lower and upper parts.The lower part of the Tarbur Formation comprises medium-bedded limestones, which consists of Iron nodules, Gastropoda and Rudist debris whereas the upper part is including Rudist and Gastropoda massive limestone with bivalve fragments. Generally, based on the identified foraminifers, Tarbur Formation is assigned to Upper Maestrichtian. According to the microscopic investigations, the index microfacieses, consists of Framestone, Wackestone, Grainestone, Packestone, Floatestone, Rudestone, Buffelestone, Omphalocyclos bioclast packstone and Loftosia bioclast Packstone (Figure 6, photos 1-3). Moreover, occurrence of foraminifera with Hyaline wall reflects the seaward part of the Tarbur carbonate depositional system. Also appearance of the Agglutinated wall genera and species have supported reef marine sedimentary environment [5].

\subsection{Microfacies of Gurpi Formation}

Gurpi formation expanded in study area in Mook and Shahneshin sections. Gurpi Formation, that with a thickness of about $500 \mathrm{~m}$ at these sections and includes thin to medium bedded bluish gray shale/marl associated with thin interlayer's of argillaceous cream limestones. Some microfacies in Gurpi formation are mudstone, pelagic foraminifera wackestone and pelagic foraminifera packestone (Figure 4, photo 1, Figure 5, photos 1 and 7 and Figure 7, photo 7).

\subsection{Microfacies and Lithofacies of the CTB}

\subsubsection{Purple Shale}

Purple shale is keybed and expanded in west of study area between Gurpi and Pabdeh formations. This layer is red and there is no conclusive evidences indicating that this time CTB exposed area. This layer is sequence boundary type 2, SB2 in sequence stratigraphy interpretation (Figure 5, photos 4 and 7). For geochemical study of purple shale 4 sample selected under to above of this layer and examined with XRF method, that results are in Table 2.

\subsubsection{Interpretation}

Sample 1 and 4 related to lower and upper part of purple shale. in Sample 1 value of Fe and Mn is high and indicated highstand systems tract HST of Gurpi formation, because in HST, value of Mn and Fe are increasing. Sample 2 and 3 related to purple shale, in these samples value of Fe (900 - 1070 ppm) and Mn (20 - 30 ppm) decreased and indicated sequence boundary type 2 SB2. Totally in sequence boundary value of $\mathrm{Mn}$ and Fe decreasing and in TST and MFS these values are increasing. Also in low $\mathrm{PH}$ of environment in deep marine shelf carbonate is soluble and silica is sediment. Changes of $\mathrm{Si}$ in samples indicated while the Purple Shale deposited depth is decrease and $\mathrm{Ph}$ is increased and finally amount of $\mathrm{Si}$ is decreased (Figure 8).

\subsubsection{Lime Sandstone, Sandy Limestone and Microconglomerate}

In East of study area CTB is SB1 and contact between Tarbur and Sachun is erosional and recognized with microconglomerate, sandstone, nodular iron oxides and Paleosol (Figure 9, photos 2-9).

\subsubsection{Gamma Log Evidences}

Changes of Gamma-Ray (GR) in subsurface sections can be used to detection and recognition disconformity, when condition of sedimentary environment are changed, for example region exposed area rate of sedimentation of radioactive elements such as Thorium and Potassium change and ratio of $\mathrm{Th} / \mathrm{K}$ increasing that this change indicative disconformity [6]. Because in study area have been used of surface data there was no evidence of GR, but some example of subsurface geology in SW of Iran show in Figure 10 [7]. 


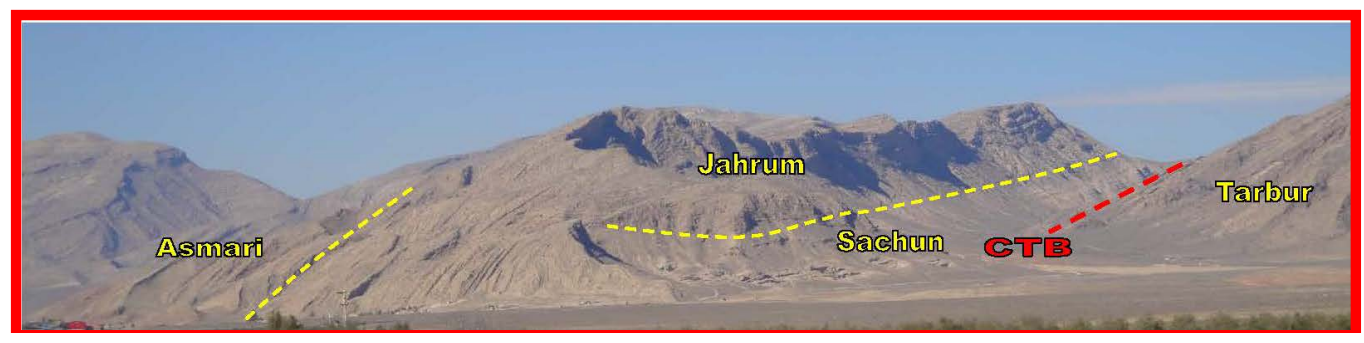

Figure 3. Field photo of Sarvestan section. Tarbur, Sachun, CTB, Jahrum and Asmari formations in East of study area.
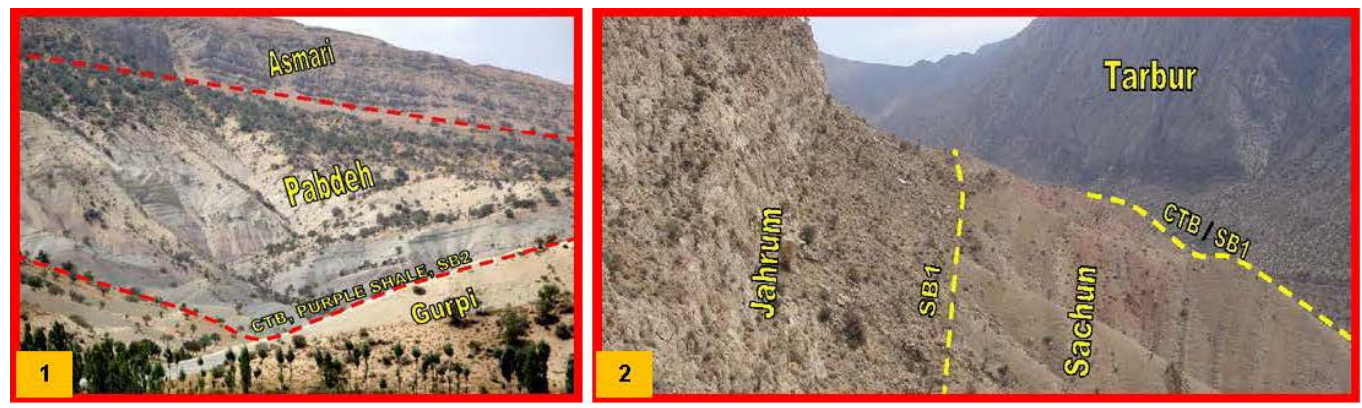

Figure 4. Field photo of CTB and formations, 1-West of study area, Shahneshin section. 2-East of study area, Sarvestan section.
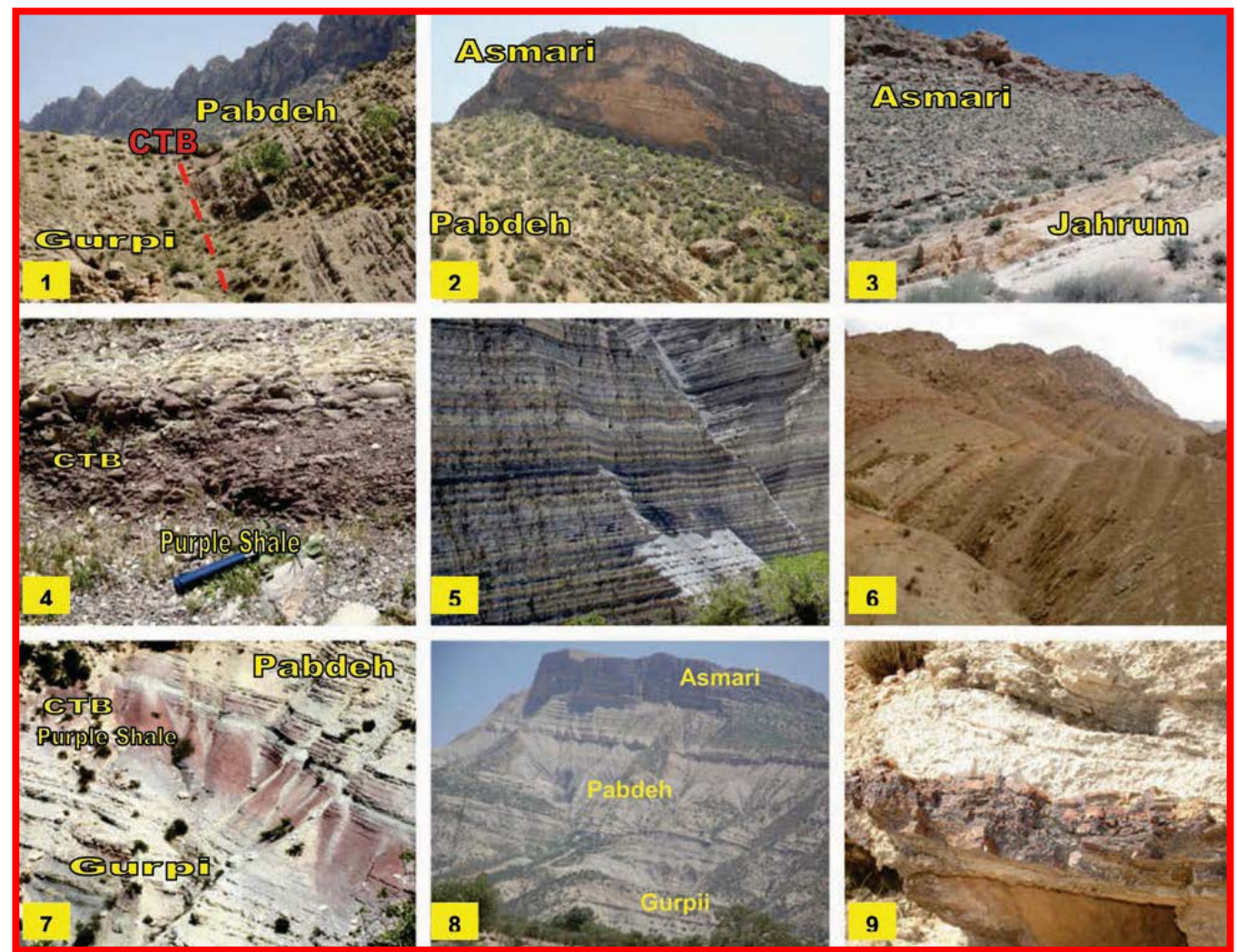

Figure 5. Some field photos of study area. 1-Purple Shale (CTB) between Gurpi and Pabdeh formations, Shahneshin section (Tang-e Abol-Hayat). 2-Pabdeh and Asmari formations, Mook section. 3-Jahrum and Asmari formation, Sarvestan section. 4-Purple shale in (CTB, SB2) base of Pabdeh formation, keybed between Gurpi and Pabdeh formations, Shahneshin section. 5-Alternative dark, blue and bright shale/marl in Pabdeh formation, Shahneshin section. 6-Alternative Evaporate layers and red shale/marl in Sachun formation, Sarvestan section. 7-Purple Shale (CTB) between Gurpi and Pabdeh formations, Shahneshin section (Sout ridge Shahneshin Anticline). 8-Grpi, Pabdeh and Asmari formation in Shahneshin section. 9-Siliceous Nodule in calcareous shale, Pabdeh formation, Shahneshin section. Real diameter size is $12 \mathrm{~cm}$. 
Table 2. Geochemical data (XRF, ppm) of samples in purple shale, CTB SB2.

\begin{tabular}{|c|c|c|c|c|c|c|c|c|c|c|c|c|c|}
\hline Location & Sample & $\mathrm{Si}$ & $\mathrm{Al}$ & $\mathrm{Fe}$ & $\mathrm{S}$ & $\mathrm{Na}$ & K & $\mathrm{Ca}$ & $\mathrm{Mg}$ & $\mathrm{Sr}$ & $\mathrm{Mn}$ & $\mathrm{P}$ & $\mathrm{Ti}$ \\
\hline Gurpi Fm. Lower part of Purple Shale & 1 & 4990 & 1830 & 1230 & 70 & 70 & 290 & 50280 & 560 & 110 & 50 & 90 & 100 \\
\hline Purple Shale & 2 & 3700 & 1490 & 900 & 200 & 50 & 250 & 51700 & 390 & 110 & 30 & 50 & 80 \\
\hline Purple Shale & 3 & 59930 & 2710 & 1070 & 220 & 60 & 380 & 18270 & 1710 & 70 & 20 & 330 & 120 \\
\hline Pabdeh Fm. Upper part of Purple Shale & 4 & 13040 & 2640 & 1670 & 110 & 100 & 510 & 43420 & 1270 & 90 & 60 & 280 & 160 \\
\hline
\end{tabular}
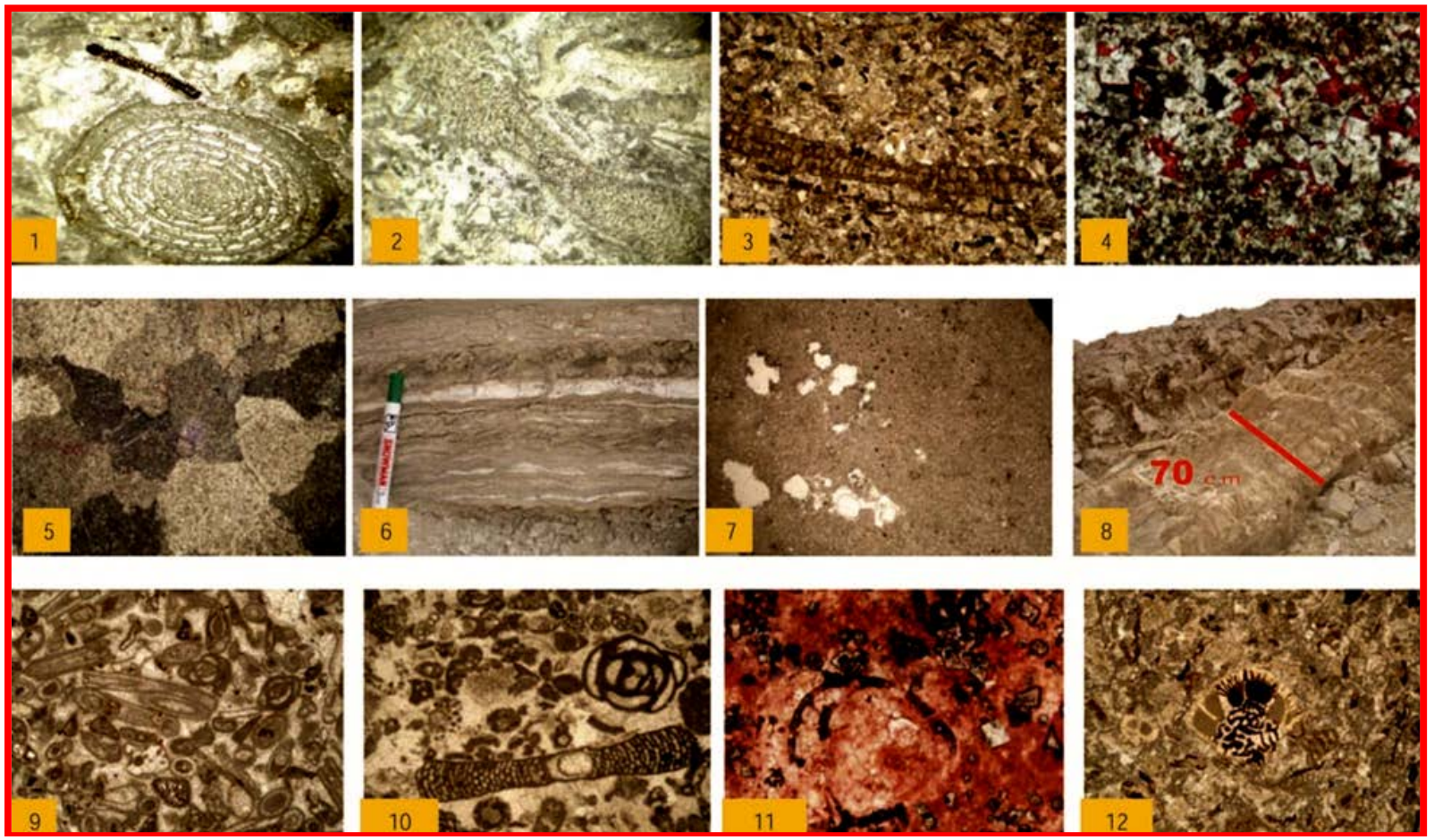

Figure 6. Some microfacies of study area. 1-Loftusia, Omphalocyclos bioclast packstone, Tarbur formation, Sarvestan section. Real size of Loftusia persica is $1 \mathrm{~cm}$. 2 and 3-Omphalocyclos bioclast packstone, Tarbur formation, Sarvestan section. Real size of Omphalocyclus macroporous is $0.8 \mathrm{~cm}$. 4-Dolomite wackestone, Jahrum formation, Sarvestan section, $\times 10$. 5Saddle dolomite, Sachun formation, Sarvestan section, $\times 10.6$ - Laminated Jypsum and Dolomite, Sachun formation, Sarvestan section. 7-Dolomudstone with fenestral fabric, Sarvestan section, $\times 4$. 8-Thick bedded of laminated Jypsum, Sarvestan section. 9-Algae bioclast grainstone, Jahrum formation, Beyza section, $\times 10.10$-Orbitolites bioclast grainstone, Jahrum formation, (Orbitolites shirazienensis, Upper paleocene), $\times 10.11$-Dolomitized bioclast wackestone, Jahrum formation, Sarvestansection, $\times 10.12$ - Rotalia bioclast packstone Jahrum formation, $\times 10$.

\section{Interpreting \& Offering Depositional Model of Cretaceous-Tertiary (CTB) in Study Area}

Based on microfacies study, sedimentary environments models and sequence stratigraphy evidences 3 depositional model based on relative sea level change is presented during CTB time in study area.

\subsection{Model A}

During cretaceous time in central and east of study area (Estahban and Sarvestan sections) carbonate Tarbur formation deposited and Equivalent to in west of study area in pelagic marine environment Gurpi formation is deposited. During CTB time totally study area exposed of marine environment and LST systems tract deposited over on these formations (Figure 11, Model A).

\subsection{Model B}

After cretaceous period and start of Paleocene in west of study area (Mook and Shahneshin sections) purple shale equivalent to Sachun formation (in central and east of study area) is deposited (Figure 11, Model B). Purple shale is keybed for lithostratigraphical separation of Gurpi and Pabdeh formations. After transgressive sea level during Paleocene Eocene in west of study area 


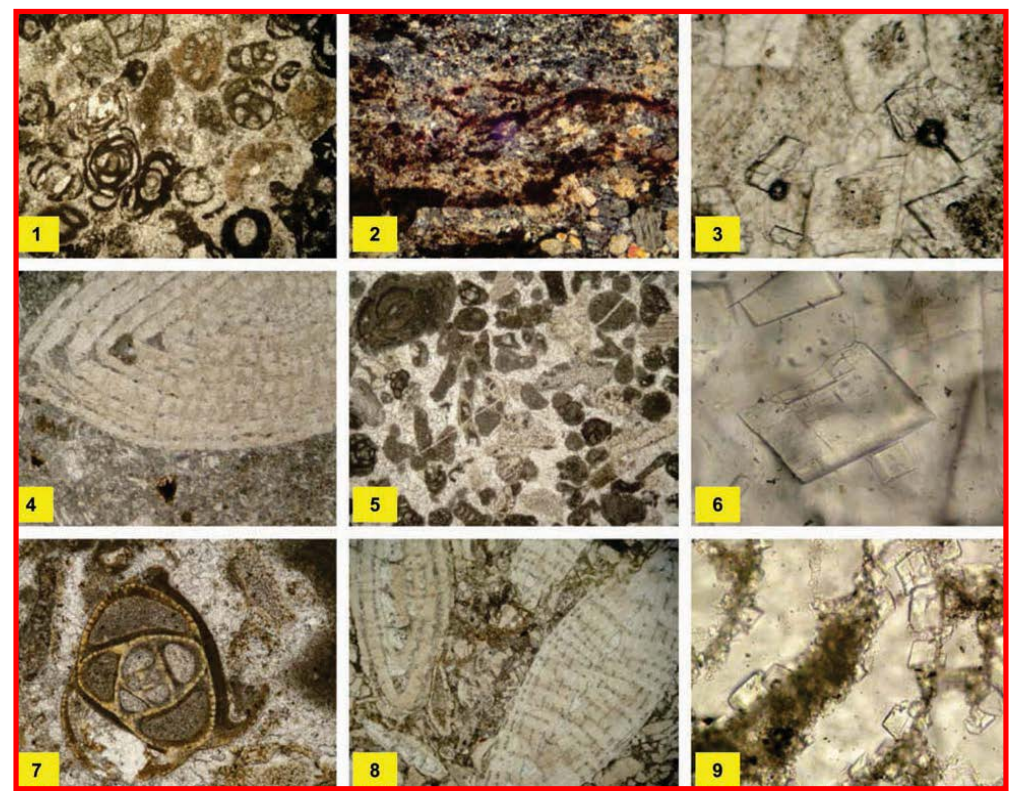

Figure 7. Some microfacies of study area. 1-Miliolid Bioclast Grainstone, Asmari formation, Sarvestan section, $\times 4$. 2Gypsum/Anhydrite, Sachun formation, Sarvestan section, $\times 4$. 3-Dolograinstone, dolomite crystal with fuggy core and clear rim, Jahrum and Asmari formations, $\times 10.4-$ Nummulites bioclast Packstone, Asmari formation, Sarvestan section, $\times 10.5-$ Algal Miliolid bioclast Grainstone, Jahrum formation, Sarvestan section, $\times 4$. 6 -Rombohedral crystal of Dolomite, Jahrum formation, Sarvestan section, $\times 40$. 7-Austrotrilina bioclast Grainstone, Asmari formation, Sarvestan section, $\times 10.8-N u m m u-$ lites bioclast Packstone, Asmari formation, Sarvestan section, (Nummulites fichtelli.) $\times 10$. 9—Rombohedral crystal secondary dolomite in Gastropod chamber and fatal fabric of dolomitization, Jahrum and Asmari formation, Sarvestan section, $\times 10$.

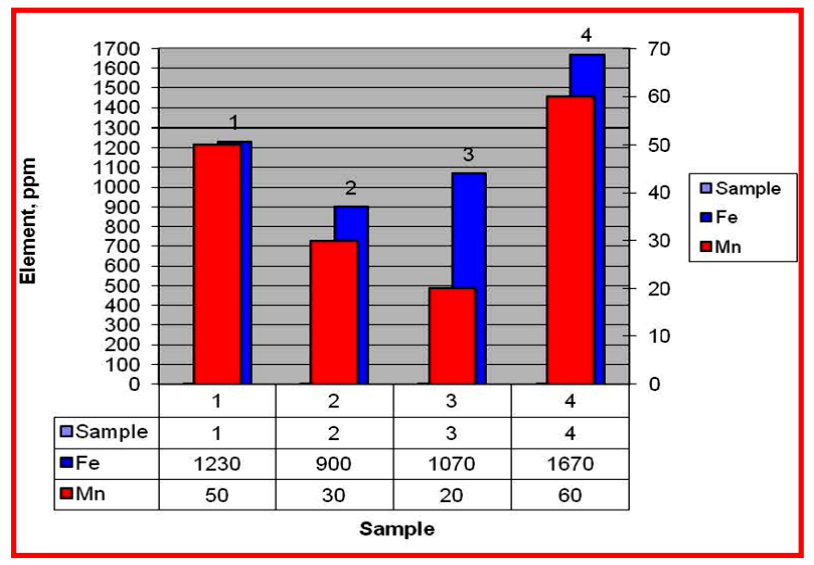

Figure 8. Distribution of $\mathrm{Fe}$ and $\mathrm{Mn}$ in samples 1 to 4 around Purple Shale, CTB, SB2.

(Mook and Shahneshin sections) purple shale and Pabdeh formation is deposited over on Gurpi formation (SB2) (Figure 11, Model B).

\subsection{Model C}

During CTB time in central and east of study area sea level is transgressive and deposited TST and HST systems trat. In this time evaporate/marly Sachun formation deposited over on carbonate Tarbur formation. In west of study area in this time Purple shale and Pabdeh formation deposited over on Gurpi formation (Figure 11, Model C).

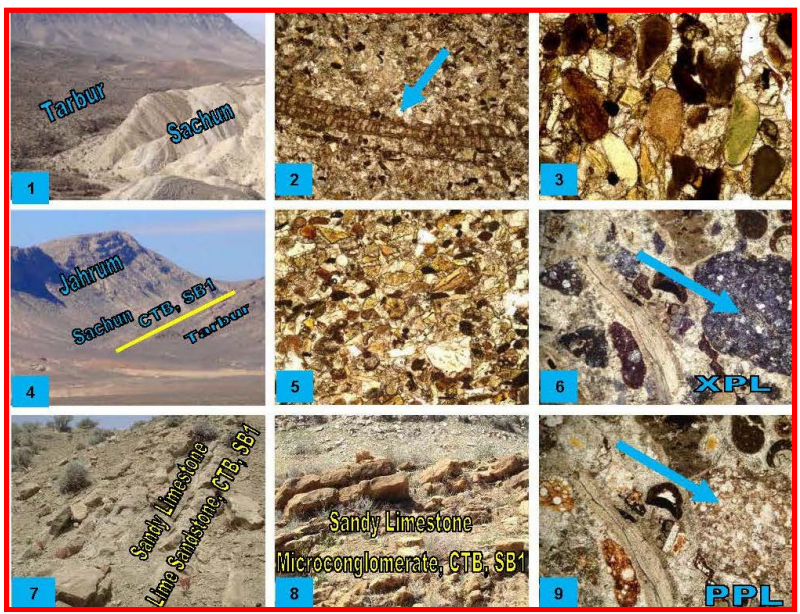

Figure 9. Some field and microfacies photos of study area. 1-Contact between Tarbur and Sachun SB1, Sarvestan section. 2-Sandy Limestone with Rework microfossils, Omphalocyclus macroporous (late maestrichtian), between Tarbur and Sachun formation, $\times 4$. 3-Lime sandstone with rounded sedimentary rocks fragments, between Tarbur and Sachun formations $\times 4.4-$ CTB, SB1 between Tarbur and Sachun formation, Paleosol with iron oxides debris, Saevestan section. 5-Sandy limestone between Tarbur and Sachun formation, Estahban section, $\times 10$. 6-Lime microconglomerate, $\times 10$, XPL. 7-Sandy Limestone and Lime sandstone between Jahrum and Asmari formations, Estahban section. 8-Sandy Limestone and Microconglomerate between Jahrum and Asmari formations, Estahban section. 9-Lime microconglomerate, $\times 10$, PPL. 

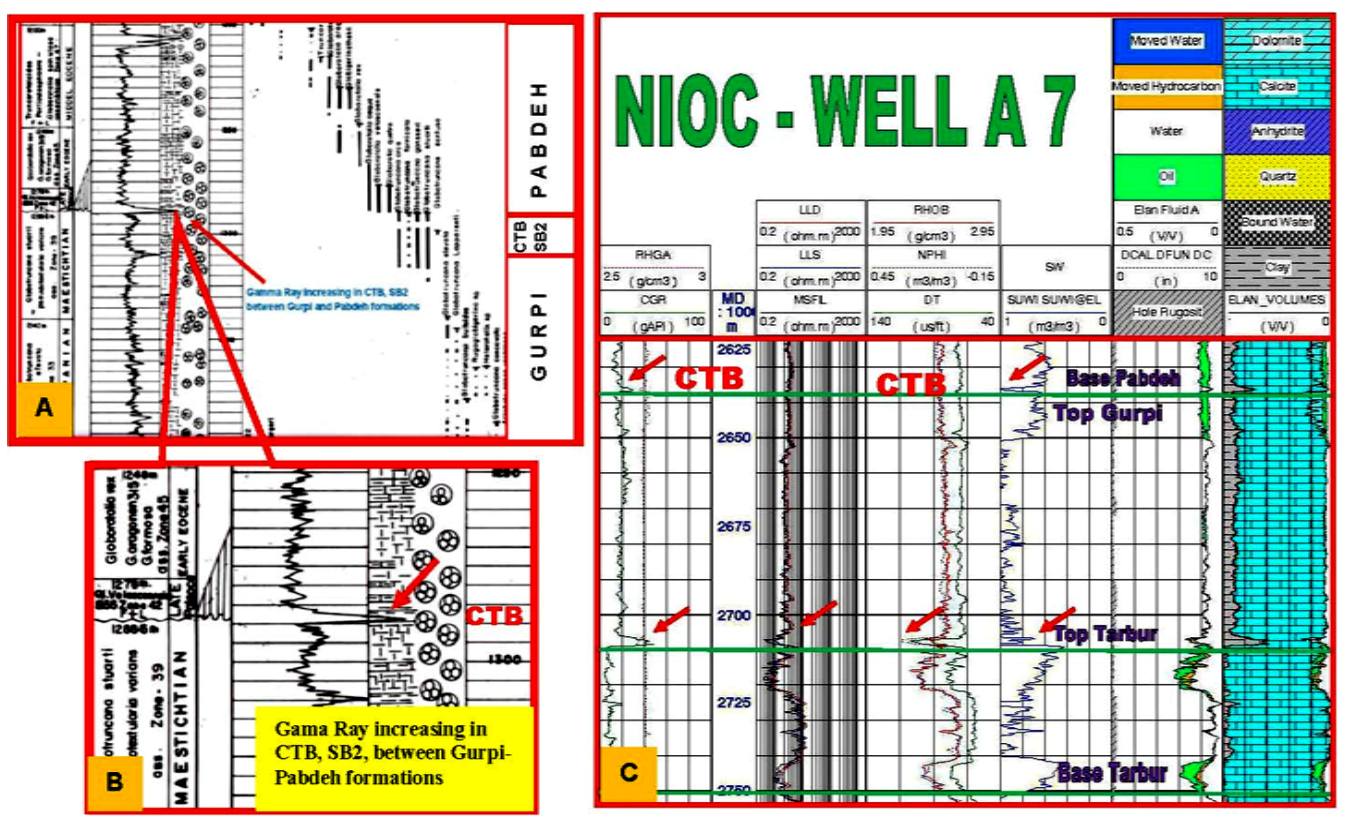

Figure 10. A and B: increasing API of GR in CTB, SB2 between Gurpi and Pabdeh formation, modified of NIOC. Persian Gulf of Iran. C: increasing API of GR in CTB, SB2 between Gurpi and Pabdeh formation, modified of NIOC. Khuzestan, SW of Iran.

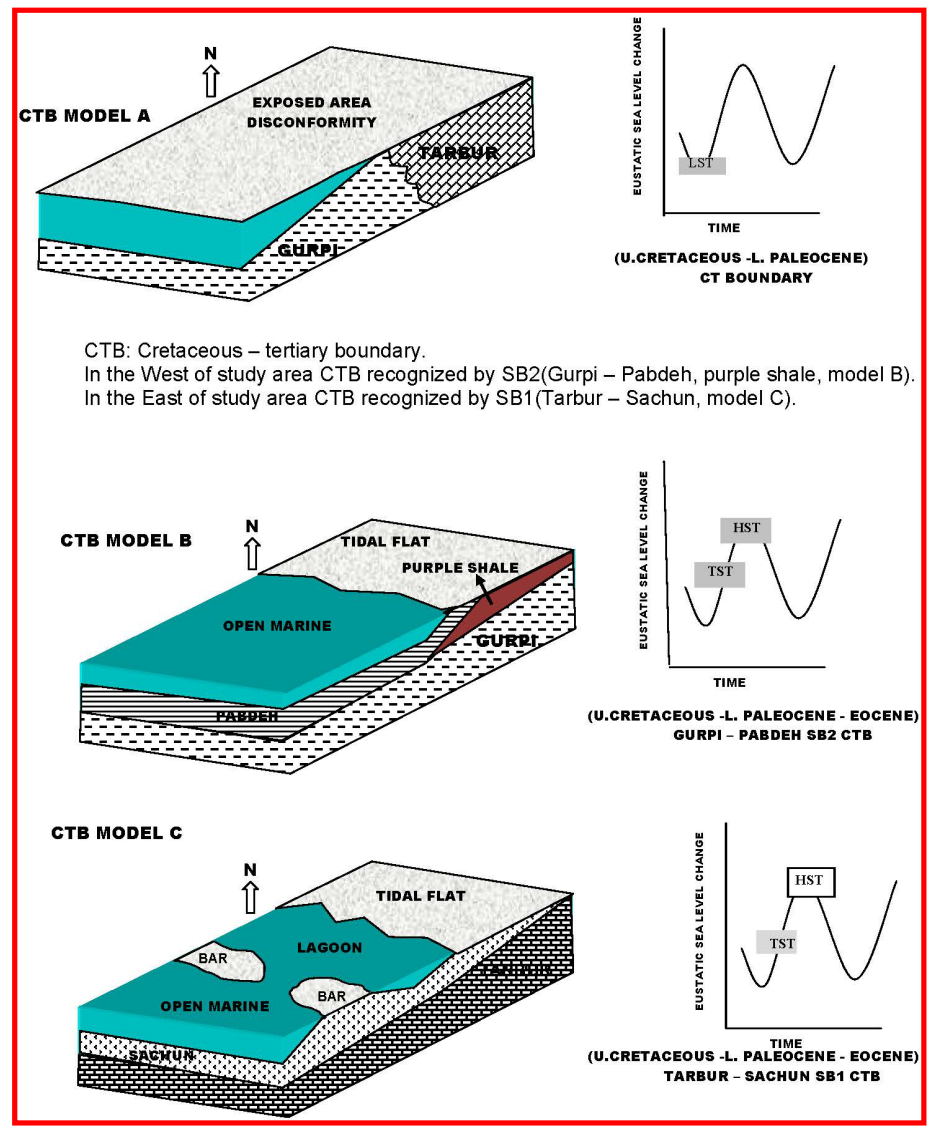

Figure 11. Depositional environment model based on sea level change during upper Cretaceous-Tertiary (CTB) in study area. A: Depositional environment model during CTB in east to west of study area. B: Depositional environment model during Upper Cretaceous-Lower Paleocene-Eocene between Gurpi and Pabdeh formations. C: Depositional environment model during Upper Cretaceous_-Lower Paleocene_Eocene between Tarbur and Sachun formations. 


\section{Microfacies of Sachun Formation}

Microfacies studies of the Sachun formation samples in Sarvestan section have shown that the Sachun formation has been made mostly from tidal flat and Lagoon facies. Some microfacies of Sachun formation summarized in Table 3 (Figure 6, photos 5, 6 and 8 and Figure 7, photo 2).

\section{Depositional Model of Sachun Formation}

Field and microfacies studies indicate that sediments of the Sachun formation have been deposited in three facies belts of tidal flat, lagoon and barrier. In the proposed model, D, C, B \& A facies are related, respectively, to supratidal, intertidal, shallow-lagoon, and back reef environment with moderate to high energy. The Sabkha environment is a salt bottom, sometimes temporarily covered by shallow wate. Microfacies studies of the Sachun formation samples in the studied section indicate that in the initial parts of the Sachun formation, a carbonate platform was deposited, while the majority of its sedimentary environment coincides with the formation of tidal environment (Figure 12, photo A).

\section{Microfacies of Jahrum Formation}

In the studied zone, the Jahrum formation has an outcrop in the Estahban and Sarvestan sections. Microfacies studies of Jahrum formation samples in the sections under study have led to the identification 13 microfacies, these microfacies summarized in Table 3. Some pictures of microfacies of Jahrum formation have been shown in Figure 6, photos 4, 5, 9-12 and Figure 7, photos 3, 5, 6 and 9.

\section{Microfacies of Pabdeh Formation}

Having carefully studied the field and microfacies samples, it was found that the identified facies in Pabdeh formation are all related to the deep marine zone, divided into two facies, plagic and re-sedimented calciturbidite limestones. The calciturbidite facies are seen on the ground as if interbedded with plagic facies. these microfacies summarized in Table 3. Some pictures of microfacies of Pabdeh formation have been shown in Figure 13, photos 1, 4 and 8.

Interpreting \& Offering Depositional Model of Jahrum \& Pabdeh Formations

The Petrographic and field observation of the Pabdeh and Jahrum formations in the studied zone shows that its sedimentary environment is related to deep marine environment, and its facies includes shale, pelagic limestone and turbidity limestone (re-sedimented) facies group. The case that turbidity and pelagic facies are interbedded and that the planktonic and benthonic fragments are mixed in turbidity limestones indicate a high rate of sedimentation, creation of turbidity currents, and carbonate slumping from a platform margin with a steep slope and its deposition in the sea depth (Figure 12, photos B and C).

Comparison of the microfacies sequences of the stratigraphic columns in the area under study as well as studying the facies of the Pabdeh and Asmari formations demonstrate that the Jahrum formation has been deposited in a carbonate platform of shelf type. Although, the carbonate platform of the Jahrum and Pabdeh shaly formations has been deposited similar in the open marine [8].

\section{Microfacies of Asmari Formation}

In the studied zone, the Asmari formation has an outcrop in the Estahban, Mook and Shahneshin sections. Microfacies studies of Asmari formation samples in the sections under study have led to identification of 12 microfacies. Regarding their changes in the stratigraphical column, these facies have been deposited in a carbonate platform, and deposited in four belts of open marine (A), barrier (B), lagoon (C), and tidal flat, (D), some microfacies summarized in Table 3. Some pictures of microfacies of Asmari formation have been shown in Figure 13, photos 5, 6, 9-12 and Figure 7, photos 1, 3, 4, 7 and 8.

\section{Depositional Model of Asmari Formation}

According to vertical distribution of the foraminifera, physical sedimentary structures, and facies geometric relations, four depositional subenvironments have been identified for the Asmari formation in the study area in Oligo-Miocene. These four sub environments include tidal flat, lagoon, barrier and the deep open marine. Given the described belts, carbonate ramp sedimentary model is suggested for Asmari formation (Figure 12, D).

\section{Sequence Stratigraphy of the Study Area}

Sequence stratigraphy is the modern knowledge of dividing sediments of a basin to sequences which are between equivalent discontinuities and continuities. Depositional sequence (DS) is the main unit of sequence stratigraphy, the upper and lower limit of which have appeared during one of the main cycles of the rise and fall of the relative sea level. Chronologically, the sequence is equivalent to the third-order sedimentary cycle comprising a large number of small-scale shallowing upward cycles or parasequences.

In general, the discontinuity surface divides younger layers from older ones, which is made up of two types: type 1 discontinuity: when the degree of falling of the sea level is more than the basin subsidence in the continental margin, and type 2 discontinuity: when the rate of falling 


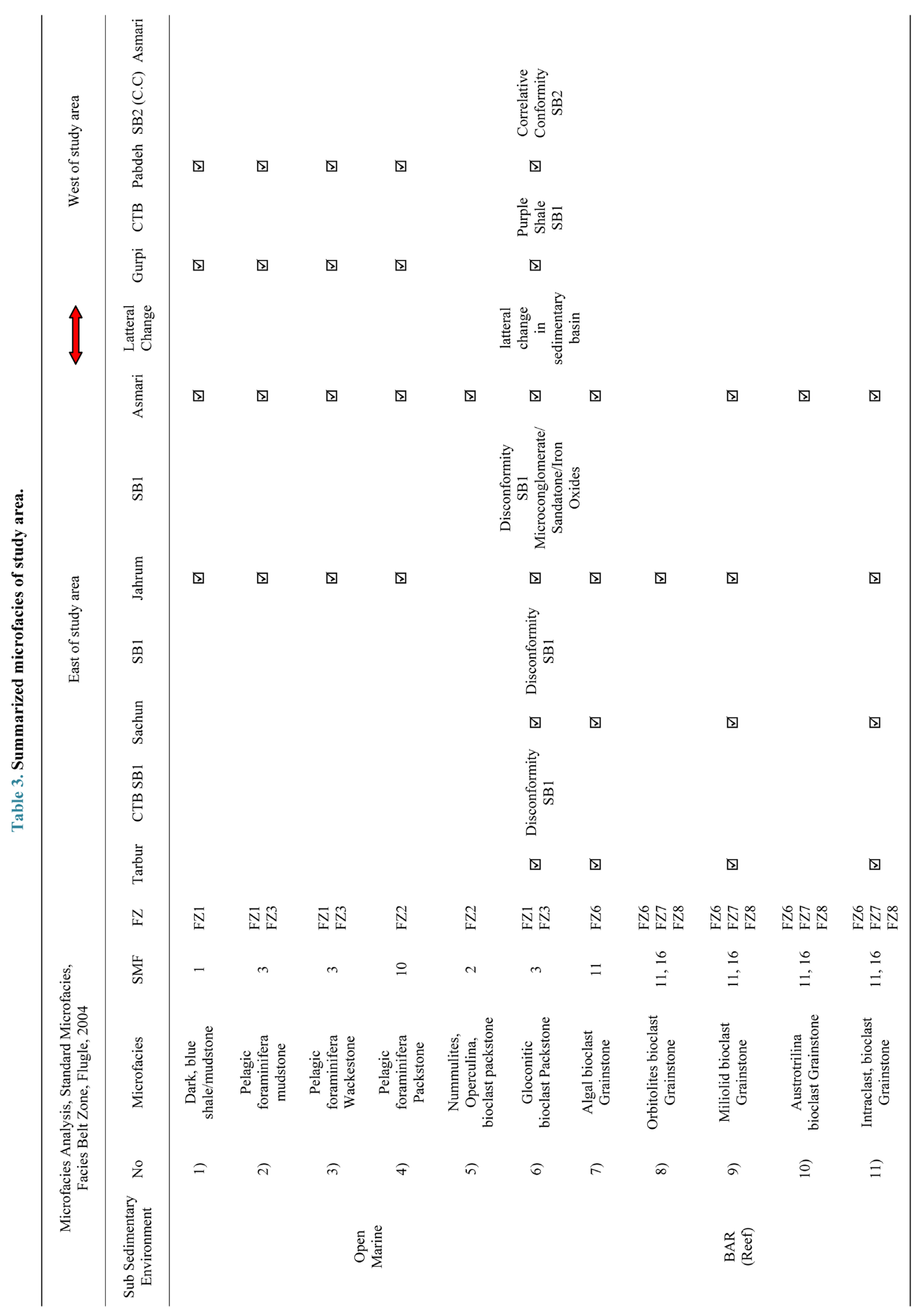




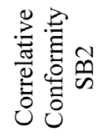

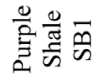

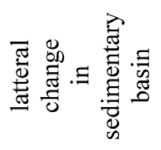

$\nabla$

$\square$

$\square$

$\nabla$

$\square \quad \square \quad \square$

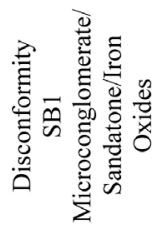

$\square$

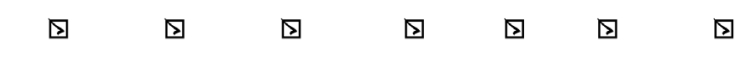<smiles>C1OC12[C@H]1C[C@@H]2C1</smiles>

$\square \quad \square$

$\square$

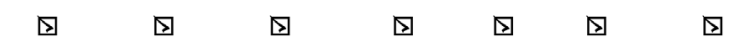<smiles>C1C2C3C1C23</smiles>

$\square \quad \square \quad \square \quad \square$

$\begin{array}{llll}\square & \square & \square & \square\end{array}$

$\nabla$

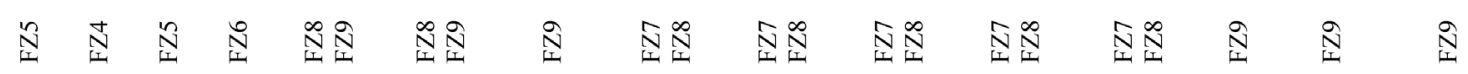

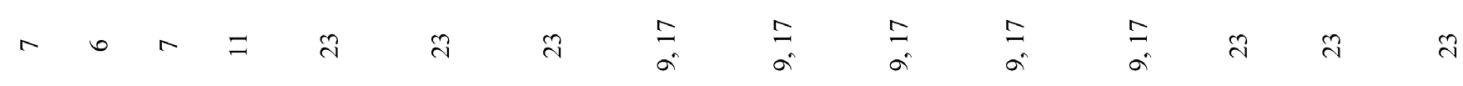

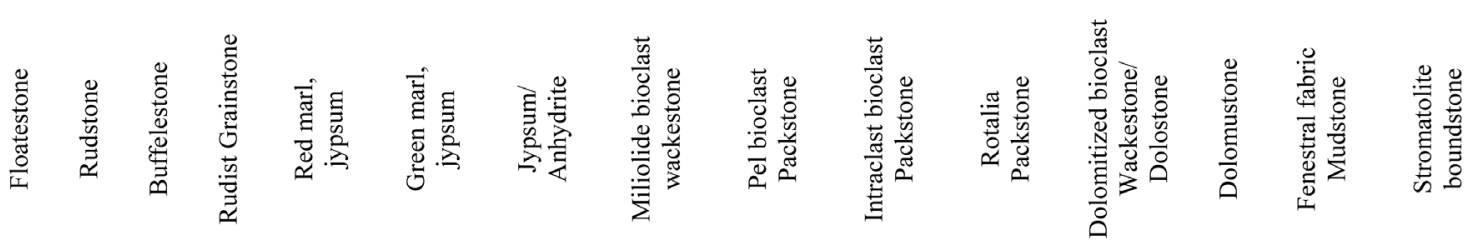

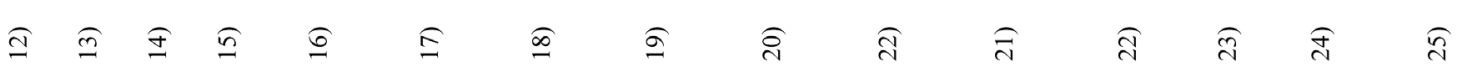

籍

望

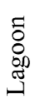

$\frac{\frac{\pi}{I I}}{\frac{\pi}{0}}$ 


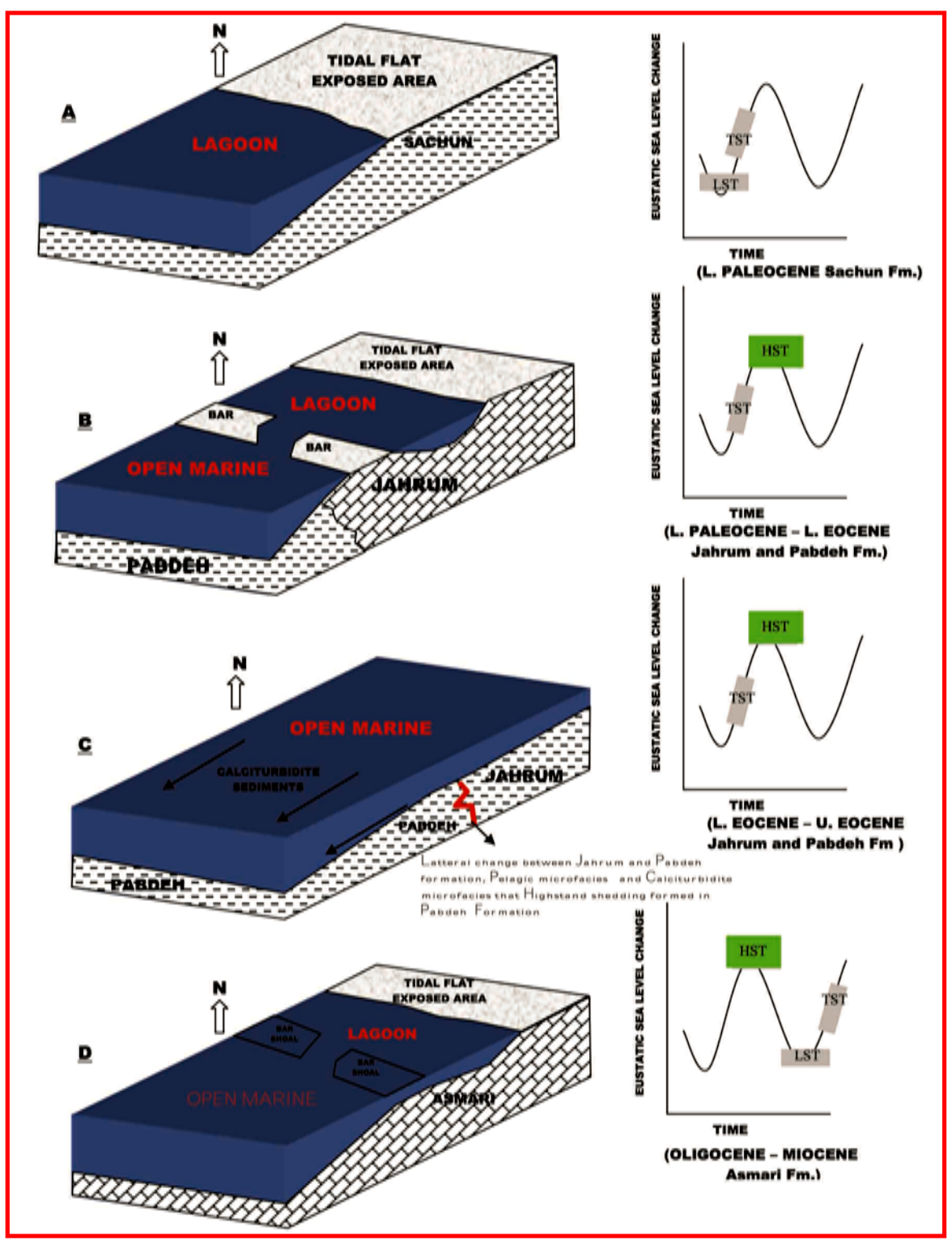

Figure 12. Depositional Model of the Studied Formations according to the Curve of Relative sea level change based on the time. A: Depositional model of Sachun formation during lower Paleocene. B: Depositional model of Jahrum and Pabdeh formation during Lower Paleocene-Lower Eocene. C: Depositional model of Jahrum and Pabdeh formation during Lower Eocene-Upper Eocene. D: Depositional model of Asmari formation during Oligomiocene.

of the sea level is slow, falling down to the middle part of the continental shelf. Each sedimentary sequence could be divided into the three systems tract, each associated with a specific part of the curve of sea level changes. The lower part of each sequence includes lowstand systems tract (LST), mainly consisting of epicontinental facies. The middle part of each sequence includes transgressive systems tract (TST) formed during seawater transgression, and the upper part of each sequence has also been formed with a systems tract related to the relative static state of seawater or the beginning of the seawater falling stage (Highstand systems tract) (HST). In sequence stratigraphic studies, references includingVail et al. (1977)
[9], Van Wagoner et al. (1988) [10], Nadjafi et al. (2004) [11], Emery and Myers (2005) [12], Schlager et al. (2005) [13], Zhang, X. et al. (2006) [14], Van Buchem et al. (2010) [15], Keller G. (2011) [16], Gang Li. et al. (2007, 2010) [17,18], Mirzaee Mahmoodabadi et al. (2013) [19, 20], have been used.

The main objective in conducting this research was to study the Tarbur, Gurpi, Sachun, Jahrum, Pabdeh and the Asmari formations with regard to the vertical distribution of various of microfacies, so that sedimentary sequences in different parts of the sedimentary basin could be studied by determining sequences and facies association, and this evidence could be applied to the stratigraphic 


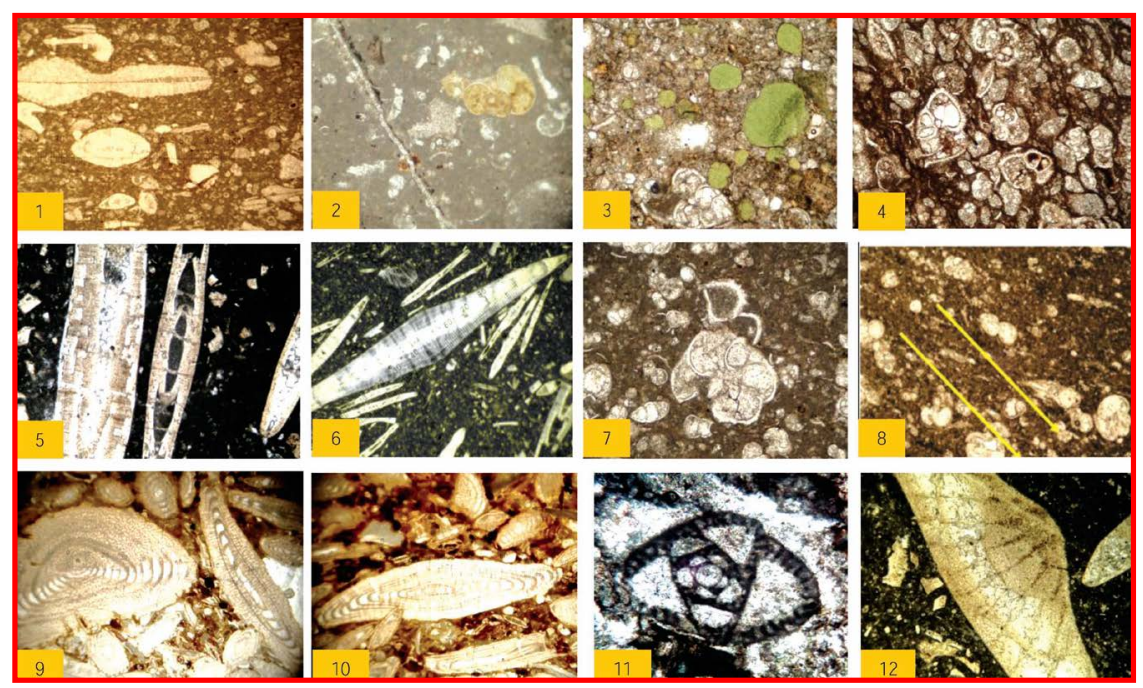

Figure 13. Some microfacies of study area. 1-Loftusia, Omphalocyclos bioclast packstone, Tarbur formation, Sarvestan section. Real size of Loftusia persica is $1 \mathrm{~cm}$. 2 and 3-Omphalocyclos bioclast packstone, Tarbur formation, Sarvestan section. Real size of Omphalocyclus macroporous is $0.8 \mathrm{~cm}$. 4-Dolomite wackestone, Jahrum formation, Sarvestan section, $\times 10.5-$ Saddle dolomite, Sachun formation, Sarvestan section, $\times 10.6$ - Laminated Jypsum and Dolomite, Sachun formation, Sarvestan section. 7-Dolomudstone with fenestral fabric, Sarvestan section. $\times 4$. 8-Thick bedded of laminated Jypsum, Sarvestan section. 9-Algae bioclast grainstone, Jahrum formation, Beyza section, $\times 10.10-$ Orbitolites bioclast grainstone, Jahrum formation, (Orbitolites shirazienensis, Upper paleocene), ×10. 11-Dolomitized bioclast wackestone, Jahrum formation, Sarvestansection, $\times 10.12-$ Rotalia bioclast packstone Jahrum formation, $\times 10$.
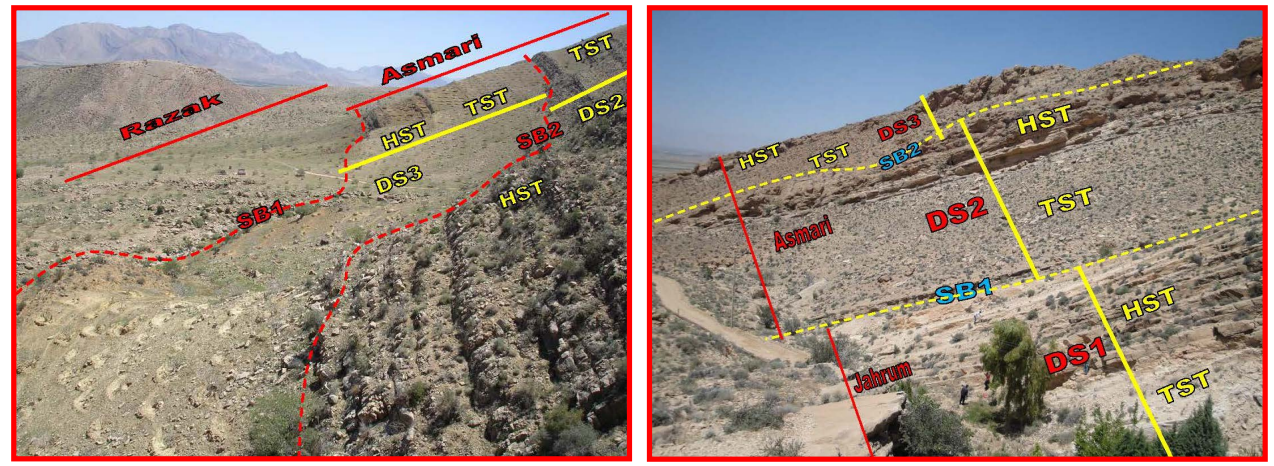

Figure 14. Sequence stratigraphy photo of Sarvestan and Estahban sections.

correlation investigation of the studied formations.

\subsection{Sequence Stratigraphy of Estahban Section}

The Estahban section with a thickness of 266 m comprises the Sachun, Jahrum and Asmari formations, and with regard to sequence stratigraphy, includes two third-order depositional sequences. As for the small outcrop of Sachun formation in this section, only the sequence stratigraphy of the Jahrum and Asmari formations are investigated. Jahrum formation in the studied section is consisted of a third-order depositional sequence (DS1). Its lower lithostratigraphic boundary is gradational and consistent with Sachun formation and its discontinuity is 2 type (SB2). The TST systems tract of this sequence, having a thickness of $75 \mathrm{~m}$, is comprised of dolomite, dolomite limestones and thin-bedded limestone. HST facies with a thickness of $105 \mathrm{~m}$ is composed of limestone and medium to thick-bedded dolomite limestones. Maximum flooding surface (MFS) is identified with plagic bioclastic wackestone. This systems tract is ended to the first type discontinuity (SB1) under depositional sequence of the Asmari formation. This boundary is distinctive on the land due to having paleosol and red beds. On this boundary the transgression of thin to mediumbedded carbonates of Asmari formations (TST facies) is started, and ends with HST facies of weathered medium to thick bedded ick-bedded limestones under Razak formation.

\subsection{Sequence Stratigraphy of Sarvestan Section}

The Sarvestan section, with a thickness of $570 \mathrm{~m}$ includes Tarbur, Sachun and Jahrum formations. This sec- 
tion includes two third-order depositional sequences, of which the second depositional sequence is common between the Sachun and Jahrum formations. Sachun evaporite facies in the Sarvestan section has a thickness of 390 $\mathrm{m}$, mainly consisting of green and red marls which have been interbedded with laminated gypsum, dolomite and dolomitic limestones. The study of vertical variation of microfacies, as well as the study of thin-bedded gypsum, dolomite, limestone, and marl facies in the field have led to the identification of a third-order depositional sequence. The identified sequence itself is comprised of several shallowing-upward sedimentary cycles. The thickness of this sequence is $350 \mathrm{~m}$. (the upper $40 \mathrm{~m}$ of the Sachun formation is related to the depositional sequence of Jahrum formation DS2), and its lower boundary (sequence boundary type Two-SB2) is identified by contact with Tarbur formation and Sachun formation. Lowermost age of Sachun formation is determined by the last occurrences of Tarbur foraminifera which is assigned to Mid-Paleocene. TST facies of the concerning sequence is related to the deeper lagoon environment; having a thickness of $140 \mathrm{~m}$, it is composed of dolomite, dolomite bioclastic wackestone, marl, stromatolite, and gypsumanhydride, and is observed on the land as gray and green marls interbedded with light gray and green dolomite and dolomite limestones. Due to dolomitization, the maximum flooding surface is not recognizable; however, it is not further than the lagoon limit.

The HST facies of the Sachun formation with a thickness of $210 \mathrm{~m}$ is composed of red marls interbedded with gypsum, anhydride, dolomitized limestone, and dolomite layers. This sequence includes several shallowing upward paracequences (red and green marl alterations).

The Jahrum formation in the Sarvestan section includes a depositional sequence (DS2), consisting of a number of small-scale or shallowing upward parasequences. TST facies of the second type depositional sequence is marked on the land by gray and green marl facies of the upper part of the Sachun formation. HST facies is more than the systems tract of the lagoon sedimentary environment and is seen as light thin to mediumbedded dolomite and dolomitized limestone. The upper lithostratigraphic limit of the Jahrum sequence marked by erosional with Asmari formation (SB1) and the upper segment of this sequence is eroded or deleted (Figure 1).

\subsection{Sequence Stratigraphy of Mook Section}

Mook section, with a thickness of 520 m, stratigraphically includes 3 formations: Gurpi, Pabdeh and Asmari. The study of vertical variations of the facies of the Pabdeh and Asmari formations in Mook has resulted in the identification of 3 depositional sequences (third class cycle). The upper and lower boundary of each of these three sequences is continuous (SB2). The first and second depositional sequence is related to Pabdeh formation and the third depositional sequence is common in the upper parts of the Pabdeh and Asmari formations. The thickness of the first depositional sequence (DS1) of Pabdeh formation is $95 \mathrm{~m}$ and its lower boundary is distinguished by the second class boundary in the lower part of purple shale (SB2).

TST facies of the first depositional sequence with a thickness of $35 \mathrm{~m}$ has been composed of mudstone/lichen and Globigerina and Globorotalia Bioclastic wackestone. The maximum flooding surface is identified by thinbedded dark shale facies. The outcrop of these facies on the ground is shown by the alternation of yellow and gray shallowing upward shale and limy shale. At the relative rest condition of the sea level, HST facies with a thickness of $60 \mathrm{~m}$ includes alternation of plagic facies and re-sedimented Nummulites limestone. The facies observed in this part includes Globigerina bioclastic wackestone, Nummulites and alveolunid bioclastic packstone, Globigerina and Nummulites wackestone, Nummulites, Discocyclina and Globigerina bioclastic packstone, algae bioclastic grainstone, intraclastic bioclastic packstone, and pallet and intraclastic bioclastic wackestone, which have been deposited on each other as shallowing upward cycles.Thickness of the second depositional sequence is $295 \mathrm{~m}$, its lower boundary is of type two (SB2) and its upper boundary, which is correlative conformity ends in the lower part of the Asmari formation. The transgression surface is started with shale facies and the maximum flooding surface (MFS) is identified by bioclastic packstone facies with glauconitization in foraminiferal pores (Figure 13, photo 3).

TST facies having a thickness of $85 \mathrm{~m}$ have been composed of shale, globigerina bioclastic mudstone, Globigerina bioclastic wackestone, and Globigerina bioclastic packstone. The outcrop of this facies on the ground includes the alternation of shale and lime shale.

HST facies, the second sedimentary sequence (DS2) with a thickness of $210 \mathrm{~m}$ has been formed with an alternation of lime shale and re-deposited limestones. The microfacies of this systems tract includes shale, Globigerina bioclastic wackestone, Nummulites and Milliolid bioclastic wackestone, pellet, intraclastic wackestone, and Nummulites and Discocyclina bioclastic packstone, and while its outcrop on the ground includes alternation of medium to thick-bedded lime shale and re-sedimented limestones. This systems tract facies, which is correlative conformity, ends below the Asmari formation. Syndepositional fault operation causes different morphology in the carbonate platform and change in the manner and type of deposition. The final result of this process could cause different sequences in the Pabdeh formation.

The thickness of the third depositional sequence is 130 $\mathrm{m}$; the upper limit of the Pabdeh formation with a thick- 
ness of $70 \mathrm{~m}$ forms the TST facies. This systems tract facies has been composed of open sea facies including shale, marl, and lime shale. The maximum flooding surface is identified by Globigerina and Globorotalia bioclastic mudstone. HST facies having a thickness of $60 \mathrm{~m}$ include the Asmari formation and is composed of lime shale and medium to thick-bedded weathered limestones. The upper limits of the third sequence have been eliminated and ended by the erosive boundary with the Razak formation (Figure 15).

\subsection{Sequence Stratigraphy of Shahneshin Section}

The Shahneshin section, with a thickness of $600 \mathrm{~m}$ includes the 3 formations of Gurpi, Pabdeh and Asmari. With regards to sequence stratigraphy, it is comprised of a third-order depositional sequence. The boundary of all sequences is of type two, and the third depositional sequence is common in the upper sections of the Pabdeh and Asmari formations.

The thickness of the first sedimentary sequence in the Shahneshin section is $150 \mathrm{~m}$, as in the Mook section, its lower boundary is identified by purple shale from the Gurpi formation. TST facies of this sequence with a thickness of $62 \mathrm{~m}$ is transgressive and includes mudstone/lichen and also Globigerina and Globorotalia bioclastic wackestone. In this systems tract, the maximum flooding surface is identified by glauconitic bioclastic packstone. This facies is seen as the alternation of yellow and gray shallowing upward shale and lime shale. In the relative static state of seawater, HST facies having a thickness of $78 \mathrm{~m}$ includes the alternation of plagic facies and Nummulites re-sedimented limestones. The facies observed in this section include pelagic bioclastic wackestone, benthic bioclastic packstone, benthic bioclastic wackestone, Nummulites, Discocyclina, and Globigerina bioclastic packstone, algae bioclastic grainstone, intraclastic bioclastic packstone, and the pellet and intraclastic bioclast wackestone have been deposited on each other as shallowing upward cycles.

The thickness of the second depositional sequence is $120 \mathrm{~m}$, and its upper and lower boundaries are of type 2 (SB2). TST facies with a thickness of $50 \mathrm{~m}$ includes shale, Globigerina bioclastic mudstone, Globigerina bioclastic wackestone, and Globigerina bioclastic wackestone. The outcrop of this facies on the ground is as the alternation of shale and lime shale.

The transgression surface is begins with shale facies and the maximum flooding surface (MFS) is identified by bioclastic packstone facies with glauconitization in foraminiferal chambers.

HST facies, the second depositional sequence (DS2) with a thickness of $70 \mathrm{~m}$ includes the alternation of lime shale and re-sedimented limestones. The microfacies of this systems tract includes shale, Globigerina bioclastic wackestone, milliolide Nummulites bioclastic wackestone, intraclastic and pallet bioclastic wackestone, and Discocyclina and Nummulites bioclastic packstone, and its outcrop on the field observation is in the alternation of medium to thick-bedded lime and re-sedimented limestones. This facies, which is correlative conformity, ends below the Asmari formation.

The thickness of the third depositional sequence is 330 $\mathrm{m}$, and the upper part of the Pabdeh formation, having a thickness of $150 \mathrm{~m}$ includes the TST facies. This facies has been made from open sea facies including shale, marl and lime shale. The maximum flooding surface is identified by Globorotalia and Globigerina bioclastic mudstone. HST facies $180 \mathrm{~m}$ thick includes the Asmari formation and has been composed of lime shale and weathered medium to thick-bedded limestones. The high rate of carbonate production in the platform when the sea level was high, led to the transport of carbonate deposits from the shallow carbonate platform to the deep sea in both the Shahneshin and Mook sections.

The existence of benthonic bioclasts and the mixture of benthonic environment and platform facies indicate a highstand shedding and carbonate slumping from the platform margin with a steep slope and its deposition in the deep marine. The mentioned facies have been deposited in the deep basin and contact the carbonate platform of the Jahrum formation (Figure 15).

\section{Investigating the Stratigraphic Correlation of the Studied Formations Based on Sequence Stratigraphic Evidences}

In the Paleogene period in the southwest of the basin, 3 third-order depositional sequences including the Pabdeh and Asmari formations have been identified. The identified sequences have a gradual facies change as we move to the center and east of the basin and turn towards the latform facies of the Sachun, Jahrum and Asmari formations.

In order to investigate stratigraphic correlation of the studied formations, the continuous contact between the Gurpi and Pabdeh formations (sequence boundary of type 2-SB2) has been considered as the datum line for correlation.

As we proceed to the east of the studied sedimentary basin, this boundary is turned to the boundary of the second type between the Sachun and Jahrum formations. Also, the discontinuous boundary of type 1 (SB1) between the Jahrum and Asmari formations is turned to drowning discontinuous correlative conformity (C.C.) in the deep basin between the Pabdeh and Asmari formations as we approach the west and southwest of the basin.

According to the identified sequences in the studied 

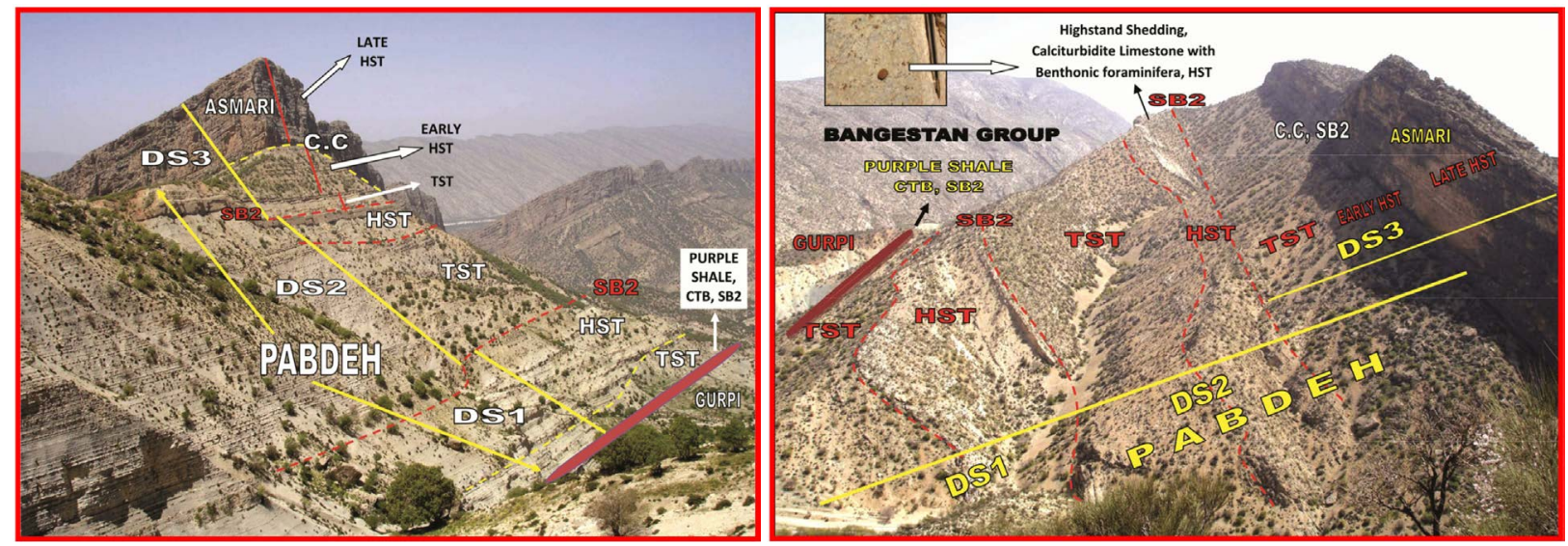

Figure 15. Sequence stratigraphy photo of Shahneshin (left) and Mook (right) sections.

sections, the purple shale section could be equalized with the Sachun formation in the east of the basin, so that during sedimentation of the green shale and marls of the Sachun formation (TST facies) in the deep basin, the drowning discontinuous contact (C.C.) or the purple shale section has been deposited.

During Oligo-Miocene, the platform sedimentary environment included almost the entire area, so that the Asmari formation has been deposited with discontinuous contact on the Jahrum formation in the east of the basin and with correlative conformity (C.C.) on the Pabdeh formation in the west and southwest area. The sediments between these two boundaries include 3 depositional sequences in which the mentioned formations could be conformed according to the systems tract and boundaries as shown in Figure 16.

\section{Conclusions}

Field and laboratory study in 4 sections in study area recognized 25 facies such as carbonate, evaporate and clastic facies.

In the west of study area CTB recognized with purple shale (SB2) and in the east of study area this contact was investigated by clastic facies (SB1).

Based on microfacies study, sedimentary environments models and sequence stratigraphy evidences 3 depositional model based on relative sea level change are presented during CTB time in study area.

The sequence stratigraphy of study area on Tarbur, Gurpi, Sachun, Jahrum, Pabdeh and Asmari formations in 4 sections indicated 4 depositional sequences in the third order.

The sequence stratigraphic study of the Sachun formation in the Sarvestan section indicates that the major part of this formation is related to depositional sequence of type 1, the lower contact of which is SB1 with the Tarbur formation, but its upper contact is continuous with green marl of the mentioned formation (SB2). The TST facies has been composed of green marl interbedded with dolomite and dolomite limestones, and the HST facies include shallowing upward parasequences comprised of red marl interbedded with gypsum.

The sequence stratigraphic study of the Sachun and Jahrum formations has resulted in the identification of 3 depositional sequences. The second depositional sequence is common between the Jahrum and Sachun formations. The TST facies of this sequence includes lagoon facies and the maximum flooding surface is identified by plagic bioclastic wackestone. The HST facies include the alternation of the lagoon environment, barrier, and tidal flat facies.

Sachun, Jahrum and Asmari formations in East of study area include 4 depositional sequences.

Pabdeh and Asmari formations in the Mook and Shahneshin sections include 3 depositional sequences in which the third depositional sequence is common between the Pabdeh and Asmari formations. They only include TST, HST facies, which are composed of shallowing upward parasequences. TST facies mostly includes alternation of lichen and thin-bedded lime shale, while the HST facies is composed of lime shale, shale and re-sedimented limestones.

The continuous contact between the Gurpi and Pabdeh formations (the second type sequence basin, SB2) has been considered as the baseline for correlation. As we proceed to the east of the sedimentary basin, this boundary then becomes the boundary of the second type between the Sachun and Jahrum formations. Also, the discontinuous boundary of type 1 (SB1) between the Jahrum and Asmari formations is turned to drowning correlative conformity contact (C.C.) in the deep basin between the Pabdeh and Asmari formations as we approach the west and southwest of the basin.

The stratigraphic correlation studies indicate that the purple shale section has been deposited equivalently to the upper part of the Sachun formation. 


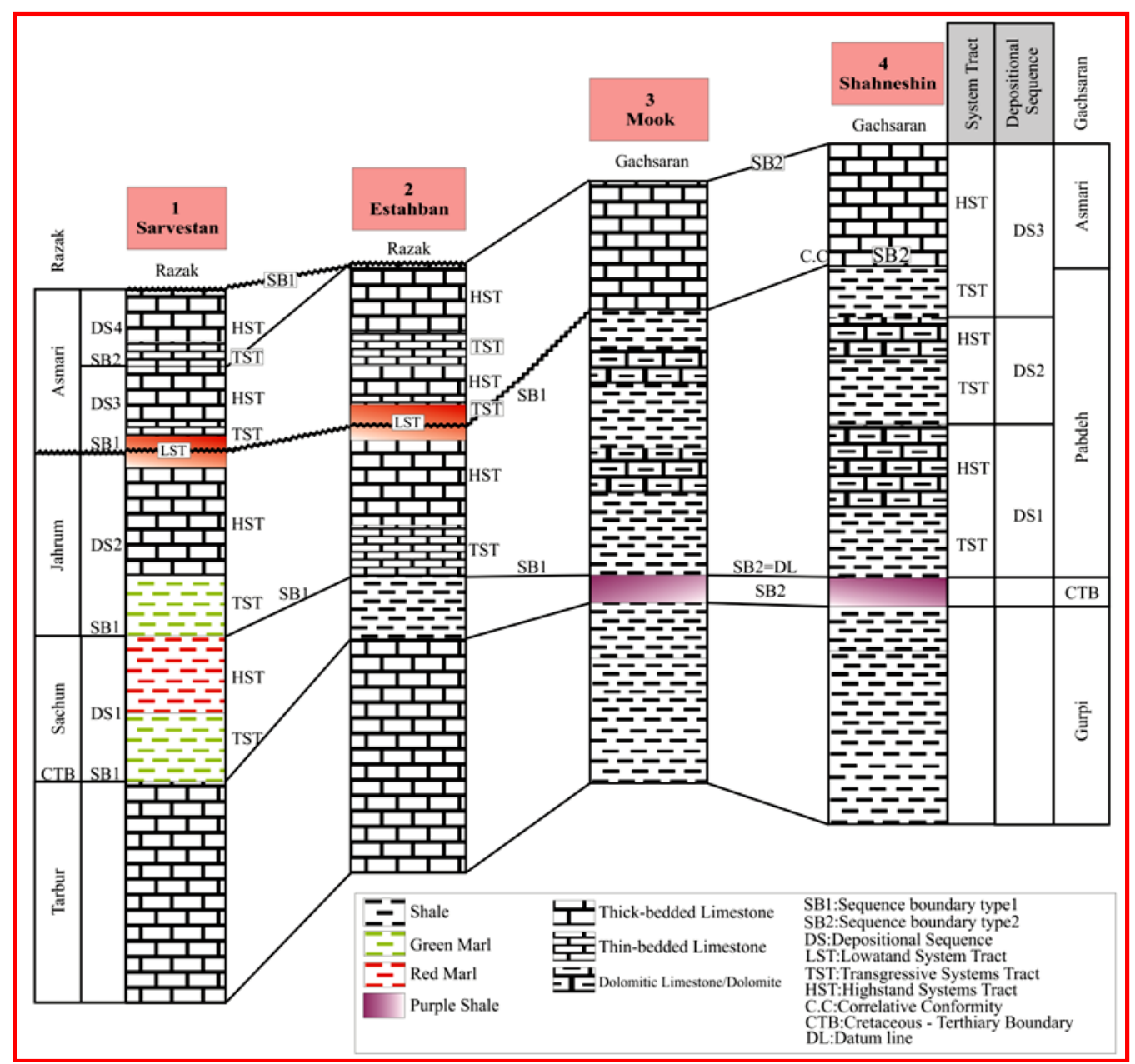

Figure 16. Stratigraphic correlation of the studied sections based on sequence stratigraphic evidences.

During Oligo-Miocene, the platform sedimentary environment included almost the entire area, so that the Asmari formation has been deposited with discontinuous contact on the Jahrum formation in the east of the basin (Estahban and Sarvestan sections) and with correlative conformity (C.C.) on the Pabdeh formation in the west and southwest area.

The conducted studies show that the facies of the Sachun formation in the zone that was studied has changed from evaporite-marl facies to marl, limes- tone, dolomite limestone, and purple shale in gradation manner as we go to the west.

\section{Acknowledgements}

This study is supported with research project of Islamic Azad University Estahban Branch, Estahban, Iran and the Author appreciates for providing the financial support.

\section{REFERENCES}

[1] H. Motiei, "Stratigraphy of Zagros," Treatise on the Ge- ology of Iran, Geological Survey of Iran, 1993, 536p.

[2] M. Alavi, "Tectonic of Zagros Orogenic Belt of Iran: New Data and Interpretations,” Tectonophysics, Vol. 229, No. 3-4, 1994, pp. 211-238. http://dx.doi.org/10.1016/0040-1951(94)90030-2

[3] E. Flugel, "Microfacies of Carbonate Rocks, Analysis, Interpretation and Application,” Springer, Berlin, p. 976.

[4] R. J. Dunham, "M1: Classification of Carbonate Rocks According to Their Depositional Texture,” AAPG, Tulsa, 1962, pp. 108-121.

[5] M. Afghah and Kh. Khosrotehrani, "Lithostratigraphic Unit and Sedimentary Environment Studies of Tarbur Formation in and North East Area of Shiraz," Journal of Islamic Azad University, Basic Sciences, Vol. 14, No. 53, 2014, pp. 4409-4439.

[6] V. E. Darvin and M. Singer, "Well Logging for Earth Scientists,” Kindle Edition, 2013, Springer, Berlin, 708p.

[7] NIOC. EXP, “Schlumberger,” Petrophysical Evaluation, Khuzestan Area, 2007, Full Set Logging.

[8] R. M. Mahmoodabadi, Y. Lasemi and M. Afghah, "Sedimentary Environment and Sequence Stratigraphy of Pabdeh Formation in Shiraz Area," Geosciences Scientific 
Quarterly Journal, Vol. 19, No. 73, 2010, pp. 139-146.

[9] P. R. F. Vail, S. A. Audemard, D. Bowman, N. Eisner and C. Perezcruz, "The Stratigraphic Signatures of Tectonics, Eustasy and Sedimentology-An Overview,” In G. Einsele, W. Ricken and A. Seilasher, Eds., Cycles and Events in Stratigraphy, Springer-Verlag, Berlin, 1988, pp. 617659.

[10] J. C. Van Wagoner, H. W. Posamentier, R. M. Mitchem, P. R. Vail, J. F. Sarg, T. S. Lutit and J. Hardenbol, “An Overview of the Fundamentals of Sequence Stratigraphy and Key Definitions,” In: C. K. Wilgus, B. S. Hasting, C. G. St. C. Kendall, H. W. Posamentier, C. A. Ross and J. C. Van Wagoner, Eds., Sea Level Changes: An Integrated Approach, SEPM Special Publication, Tulsa, 1988, p. 42.

[11] M. Nadjaf, A. Mahboubi, R. Moussavi-Harami and R. Mirzaee, "Depositional History and Sequence Stratigraphy of Outcropping Tertiary Carbonates in the Jahrum and Asmari Formations, Shiraz Area (SW Iran)," Journal of Petroleum Geology, Vol. 27, No. 2, 2004, pp. 179-190. http://dx.doi.org/10.1111/j.1747-5457.2004.tb00052.x

[12] D. Emery and K. Myers, "Sequence Stratigraphy,” Blackwell Science, Oxford, p. 297.

[13] W. Schlager, "Carbonate Sedimentology and Sequence Stratigraphy,” SEPM, Tulsa, 2005, 200p. http://dx.doi.org/10.2110/csp.05.08

[14] X. Q. Zhang, J. N. Lin, G. Li and Q. X. "Non-Marine Cretaceous-Paleogene Boundary Section at Datang of Nanxiong, Northern Guangdong," Journal of Stratigraphy, Vol. 30, 2006, pp. 327-340. (in Chinese)

[15] F. S. P. Van Buchem, T. L. Allan, G. V. Laursen, M. Lotfpour, A. Moallemi, S. Mobini, H. Motiei, N. A. H. Pickard, A. R. Tahmasbi, V. Vedrenne and B. Vincent,
"Regional Stratigraphic Architecture and Reservoir Types of the Oligo-Miocene Deposits in the Dezful Embayment (Asmari and Pabdeh Formations) SW Iran,” Geological Society, London, Special Publications, Vol. 329, No. 1, 2010, pp. 219-263.

[16] G. Keller, "Difining the Cretaceous-Tertiary Boundary: A Practical Guide and Return to First Principles," SEPM (Society for Sedimentary Geology), Tulsa, 2011, pp. 2342.

[17] G. Li, X.-Q. Wan, H. Willems and D. J. Batten, "Revision of the Conchostracan Genus Tenuestheria from the Upper Cretaceous Lanxi Formation in Zhejiang and Its Biostratigraphic Significance in Southeast China,” Acta Geologica Sinica, Vol. 81, No. 6, 2007, pp. 925-930. http://dx.doi.org/10.1111/j.1755-6724.2007.tb01015.x

[18] G. Li, H. Hirano, D. J. Batten, X. Q. Wan, H. Willems and X. Q. Zhang, "Biostratigraphic Significance of Spinicaudatans from the Upper Cretaceous Nanxiong Group in Guangdong, South China," Cretaceous Research, Vol. 31, No. 4, 2010, pp. 387-395. http://dx.doi.org/10.1016/j.cretres.2010.05.003

[19] R. Mirzaee Mahmoodabadi, "Depositional Environments and Sequence Stratigraphy of Paleocene-Eocene Sediments in Shiraz Area, Fars, Zagros, Iran,” Oral, IAS (International Association of Sedimentology), Manchester, 2013.

[20] R. Mirzaee Mahmoodabadi, "Paleoecology and Quantitative Study of Bentonic and Pelanktonic Foraminifera of Pabdeh Formation Based on Sequence Stratigraphy Evidences in Shiraz, Fars, Zagros, Iran,” Poster, IAS (International Association of Sedimentology), Manchester, 2013. 